After these important recommendations of principle it is perhaps unfortunate that the committee has concerned itself at this stage with the detailed layout of individual records. Thus the suggestion that a single record should serve both as an identification sheet and for abstracts of repeated episodes of both in-patient and out-patient treatment implies so many radical changes in procedure and format that it might be more suitable for a pilot study than for national use. There are also coding ambiguities and errors of layout in the proposed form, and it might well be withdrawn for further study.

A striking feature of the field of medical records is the almost complete absence of data on which to base future policy. We hope that the permanent body which the committee recommends should be set up will encourage the basic operational research which is so badly needed.

\section{Sonne Dysentery}

In the last 15 years Sonne dysentery has established itself as one of the most prevalent infectious diseases in this country. During the 1950s the average number of notifications in England and Wales was just over 30,000 per annum, but this represents only a fraction of the total number of infections with Shigella sonnei in the community, for many cases go unrecognized. The highest figure recorded was 49,009 notifications in 1956. Food-borne outbreaks are now rare, and the disease spreads mainly by contact. Patients suffering from an acute diarrhoeal attack are more infectious than symptomless excreters. Young children are the chief sufferers and probably also the main spreaders of the disease. The infection is therefore a problem in nurseries, nursery schools, and the infant departments of schools. When introduced into a family it tends to spread widely, particularly in the younger members.

Outbreaks of Sonne dysentery have proved very difficult to control. Trials of chemoprophylaxis in nurseries failed to show any clear benefit. ${ }^{1}$ During outbreaks it is usual to attempt to control spread by paying increased attention to washing of hands and to hygiene in the lavatory. There are some who believe that this disease is so trifling, and control so difficult, that to remain inactive while the outbreak runs its course is the only sensible course. Admission to hospital for treatment is seldom justified, but circumstances do sometimes call for isolation in hospital.

Treatment, which at one time appeared to be fairly simple, has become more complicated since the appearance of drugresistant strains of Shigella sonnei. To have any effect on the spread of infection treatment must be started as soon as possible, because it is the early stages of the disease that appear to be the most infectious. But the single sporadic case may be difficult to diagnose without laboratory examination, which takes time. However, Sonne dysentery has a well-defined seasonal maximum in late winter and early spring, and within this period an epidemic in any one locality may be intense and of fairly short duration. Once its existence is recognized a presumptive diagnosis can often be made on the occurrence of suspicious symptoms, allowing the appropriate treatment to be begun while waiting for bacteriological confirmation.

During the last few years the most popular form of treatment has been a combination of sulphonamide and oral streptomycin. ${ }^{23}$ Although strains of Shigella sonnei resistant

\footnotetext{
1 Group Report, Brit. med. F., 1955, 2, 939.

2 Stoker, D. J., ibid., 1962,.1, 1179.

3 Ibid., 1964, 1, 825 .'
}

to either or both of these drugs are being detected with increasing frequency, the finding that the strains in a district are resistant does not mean that they will remain so permanently. A report from Drs. P. J. Moorhead and H. E. Parry in this issue of the B.M.F. (page 913) of their experience in Liverpool illustrates the point. Whereas in $196326 \%$ of the strains tested were resistant to streptomycin, in 1964 only $8 \%$ were resistant, and there were corresponding changes in the results of treatment with streptomycin. The conclusions of Moorhead and Parry on the choice of drugs for treatment may or may not be relevant to conditions elsewhere, but their description of the benefits that can come from close collaboration between clinicians and the laboratory should be studied by all who wish to obtain the best results in the treatment of this troublesome disease.

\section{Haemorrhagic Fevers}

Widespread interest in haemorrhagic fever originated around 1951 when reports began to appear of its occurrence in epidemic form among United Nations troops fighting in the central sector in the Korean war. The first account of the outbreak in English literature was that of N. M. Kater, ${ }^{1}$ and many others 'followed. Several hundred cases were reported in the campaign. The condition was first mistaken for a new disease, but later study showed that Japanese troops had met with it in Manchuria in 1935 and it had been known by a variety of local names such as Songo fever. Russian workers had also encountered this and similar fevers. ${ }^{2}{ }^{3}$ From Russia too about 1950 came reports of similar but clinically distinguishable haemorrhagic fevers-in the Crimea, in Turkmen (bordering on northern Iran), ${ }^{5}$ in the Carpathian foothills, ${ }^{6}$ and elsewhere.

A. A. Smorodintsev and his colleagues ${ }^{2}$ showed that the fevers in this group are caused by a filter-passing virus present in the blood and urine of patients during the first five days of their illness. The disease was reproduced in monkeys and human volunteers by injecting material containing the virus, but intranasal, intragastric, and intrapharyngeal inoculation was not followed by infection. The evidence suggested that the reservoirs of infection were various field rodents and that from these the disease was transmitted to man by certain ticks and mites. Clearly military operations afford greater opportunities for such transmission than usual peacetime conditions.

In the years that have followed these studies similar haemorrhagic fevers have been reported from widely spaced regions-in the Philippines and Thailand, ${ }^{7}$ Calcutta, ${ }^{9}$ South India, as Kysanur forest disease, ${ }^{9}$ the Argentine, ${ }^{10} 11$

\footnotetext{
1 Kater, N. M., Med. F. Aust., 1951, 2, 824.

2 Smorodintsev, A. A., ed. Etiologia i klinika gemorragicheskogo nefrozonefrita. Moscow. 1944.

${ }^{3}$ Bilibin, A. F., "Semiotika $i$ diagnostika infektsionnykh boleznei, p. 197 Moscow, 1950

ibid., p. 200. Moscow, 1950.

Semyatkovskaya, Z. V., and Sidtdykova, N. K., Klin. Med. (Mosk.), 1950, 28, Part 8, 69.

${ }^{6}$ Kolachev, A. R., and Kosovskii, Iu. Iu., ibid., 1949, 27, Part 8, 42.

7 Hammon, W. McD., Rudnick, A., and Sather, C. E., Science, 1960 131, 1102 .

${ }^{8}$ Chaudhuri, R. N., Chatterjee, J. B., Saha, T. K., and Chaudhuri, A. D., Bull. Calcutta Sch. trop. Med., 1964, 12, 1

${ }^{9}$ Work, T. H., and Trapido, H., Ind. F. med. Sci., 1957, 11, 341.

10 Greenway, D. J., et al., Puhl. Hlth. Rep., 1959, 74, 1011.

$"$ Molteni, H. D., Guarinos, N. C., Petrillo, C. O., and Jaschek, F., Sem. med. (B. Aires), 1961, 118, 839.

${ }^{12}$ Chew, A., et al., Lancet, $19611,307$.

${ }^{13}$ Rudnick, A., Eu Tan, E., Lucas, J. K., and Bin Omar, M., Brit. med. F., $1965,1,1269$.
} 